\title{
THE INFLUENCE OF LEADERSHIP BEHAVIOUR ON ORGANISATIONAL CITIZENSHIP BEHAVIOUR IN SELF-MANAGED WORK TEAMS IN MALAYSIA
}

\author{
Authors: \\ Zoharah Omar ${ }^{1}$ \\ Arifin Zainal ${ }^{2}$ \\ Fatimah Omar ${ }^{2}$ \\ Rozainee Khairudin ${ }^{2}$

\section{Affiliations:} \\ ${ }^{1}$ Department of Professional \\ Development and \\ Continuing Education, \\ Universiti Putra Malaysia, \\ Malaysia \\ ${ }^{2}$ School of Psychology and \\ Human Development, \\ Universiti Kebangsaan \\ Malaysia, Malaysia \\ Correspondence to: \\ Zoharah Omar \\ e-mail: \\ zoharah@educ.upm.edu.my
}

\section{Postal address:}

Department of Professional

Development and

Continuing Education,

Faculty of Educational

Studies, Universiti Putra

Malaysia, 43000, Serdang

Selangor, Malaysia

\section{Keywords:}

transformational

leadership; transactional

leadership; organisational

citizenship behaviour;

self-directed work team;

self-managing work team

Dates:

Received: 05 Apr. 2009

Accepted: 14 Aug. 2009

Published: 20 Oct. 2009

How to cite this article:

Omar, Z., Zainal, A.,

Omar, F., \& Khairudin,

R. (2009). The influence of

leadership behaviour on organisational citizenship behaviour in self-managed work teams in Malaysia. $S A$ Journal of Human Resource Management/SA Tydskrif vir Menslikehulpbronbestuur 7(1), Art. \#209, 11 pages. DOI: 10.4102/sajhrm.v7i1.209

\section{This article is available} at:

http://www.sajhrm.co.za

(c) 2009. The Authors. Licensee: OpenJournals Publishing. This work is licensed under the

Creative Commons

Attribution License.

\section{ABSTRACT}

This study examined the influence of transformational-transactional leadership behaviour on organisational citizenship behaviour in self-managed work teams and the augmenting effect of transformational-transactional leadership behaviour. This cross-sectional correlation study was conducted on 93 self-managed work teams in a multinational manufacturing company. Data were collected through group face-to-face administration by the researcher and statistically analysed through Pearson correlation, partial correlation and multiple regressions. Results showed that both transactional and transformational leadership behaviour have a positive influence on organisational citizenship behaviour among team members. Transformational leadership behaviour, however, has a greater influence on organisational citizenship behaviour compared to transactional leadership behaviour. The results also confirmed the augmenting effect of transformational leadership behaviour on the relationship between transactional leadership behaviour and organisational citizenship behaviour.

\section{INTRODUCTION}

The shift from the use of strict hierarchical structures and individualised jobs to team-based work designs, such as self-managed work-team structures, has increased the importance of employees' behaviours that are beyond employees' formal role requirements to ensure organisational effectiveness (Borman, 2004; Farh, Zhong \& Organ, 2004; LePine, Erez \& Johnson, 2002). This is because, unlike traditional work settings, self-managing work-team environments require members to assume many of the functions otherwise ascribed to management, such as assigning tasks to members, scheduling breaks, scheduling work and determining work methods (Katzenbach \& Smith, 1993; Manz \& Sims, 1993; Wellins, Byham \& Wilson 1991), in the absence of strict control from their supervisors (Campion, Medsker \& Higgs, 1993; Cohen, Ledford \& Spreitzer, 1996). Furthermore, in such work systems, employee behaviours cannot be easily observed and reinforced (Cappelli \& Rogovski, 1998) because the employees are mostly responsible for managing their own work. Such work systems require team members to take up 'extra-roles' by undertaking tasks that are above and beyond the call of their duty to help team members so that their work teams function effectively (LePine et al., 2002; Smith, Organ \& Near, 1983). Behaviours such as volunteering to carry out tasks that are not formally a part of the job, persisting with extra effort when necessary, helping and cooperating with other people serve as a critical catalyst to organisational effectiveness (Borman, 2004). Such discretionary behaviour or extrarole behaviour is described as organisational citizenship behaviour (George \& Bettenhausen, 1990; LePine et al., 2002; Organ, 1988; Podsakoff, Ahearne \& MacKenzie, 1997; Smith et al., 1983; Van der Vegt, Van de Vliert \& Oosterhof, 2003).

According to Smith et al. (1983), organisational citizenship behaviour cannot be accounted for by the same motivational bases that induce people to join, stay and perform within contractual, enforceable role prescriptions. Organisational citizenship behaviour is therefore not easily enforced by reward or by the threat of sanction because much of such behaviour has altruistic characteristics that are often subtle and difficult to measure (Smith et al., 1983). If such is the case, how does one instil such behaviour among employees at the work place, especially in a self-managed work-team structure? Literature and past research have proposed several antecedent factors that have either a direct or an indirect influence on citizenship behaviour. One of these antecedents is leadership behaviour (George \& Bettenhausen, 1990; Pearce \& Herbik, 2004; Podsakoff, MacKenzie, Paine \& Bachrach, 2000; Smith et al., 1983; Van der Vegt et al., 2003). Leadership behaviours involved mainly in the study of organisational citizenship behaviour are transformational and transactional leadership behaviours. These two types of leadership behaviours are regarded as important in work-team structures (Jung \& Avolio, 1999; Pearce \& Sims, 2002; Pillai \& Williams, 2003).

Despite its importance, most studies on transformational leadership behaviour have focused on its impact on in-role performance and follower satisfaction (Judge \& Piccolo, 2004; Rowold, 2008; Vecchio, Justin \& Pearce, 2008) rather than on 'extra-role' performance (Podsakoff et al., 1997). These studies therefore did not capture the most important effects of transformational leadership behaviour. The essence of transformational leadership is that leaders involved cause followers to do more than they are originally expected to do' and to be willing to 'transcend self-interest for the sake of the organization' (Yukl, 2002, p. 267). Podsakoff et al. (1997) reported in their study that an indirect relationship exists between transformational leadership behaviour and organisational citizenship behaviour. According to Lim and Polyhart (2004), there is still very little published empirical research on leadership in self-managed work-team structures. Besides that, much existing research on the topic of organisational citizenship behaviour was conducted with individuals as the target of examination. Recent literature and past research have shown that organisational citizenship behaviour is not only manifested in individual behaviour but also observable in teams and groups (George \& Bettenhausen, 1990; Pearce \& Herbik, 2004; Podsakoff et al., 1997; Randel, 2003). Only a few organisational citizenship behaviour researchers, however, have examined this behaviour at group-level analysis (Schnake \& Dumler, 2003). 
Furthermore, it is one of the fundamental propositions in the theory of transformational-transactional leadership behaviour that transformational leadership augments or supplements the impact of transactional leaders' behaviour on employee outcome and that transformational leadership is unlikely to be effective without transactional leadership behaviour (Den Hartog, Van Muijen \& Koopman, 1997; Judge \& Piccolo, 2004; Lowe, Kroeck \& Sivasubramaniam, 1996; Podsakoff, MacKenzie, Moorman \& Fetter, 1990). Even though this proposition is often discussed however, it has not been widely tested empirically (Judge \& Piccolo, 2004). Judge and Piccolo (2004) conducted a metaanalysis to investigate the augmenting hypothesis of the impact of transformational-transactional leadership behaviour on in-role performance and on followers' satisfaction and motivation. They found that transformational leadership appears to be generally a stronger predictor for criteria that reflect follower satisfaction and motivation, while transactional leadership behaviour tends to have a stronger influence on in-role performance. Employee organisational citizenship behaviour is an extrarole behaviour, however, not formally rewarded or punished by the organisation, unlike in-role job performance (Organ, 1988). The augmenting effect of transformational-transactional leadership behaviour on organisational citizenship behaviour therefore needs to be investigated because the manifestation of organisational citizenship behaviour is not the same as in-role job performance.

Accordingly, the purpose of the present study is to examine the influence of transformational-transactional leadership behaviour on organisational citizenship behaviour. The study also examines the augmenting effect of transformationaltransactional leadership behaviour in predicting organisational citizenship behaviour in self-managed work teams. It is important for such a study to be conducted because, in a selfmanaging work-team environment, team members often fulfil many roles and responsibilities performed by supervisors in a traditional work setting. Most of these functions are not easily observed and require team members to voluntarily take their own initiative or perform tasks beyond their job scope. This study therefore adds to the body of knowledge in determining the extent to which leadership factors influence team members' organisational citizenship behaviour.

\section{Transformational-transactional leadership behaviour}

Self-management does not imply that self-managed work teams function without leaders. Self-managed work teams must still receive directions and instructions from a person at a higher level in the organisation (Yukl, 2002). According to O'Connell, Doverspike and Cober (2002), although work teams tend to hold a greater degree of responsibility for their self-management than traditional work groups, they often still have a designated or external leader who plays a significant leadership role. External leaders play an important role in team effectiveness because selfmanaging work teams are rarely delegated with full decisionmaking authority (Morgeson, 2005). 'External leaders' refers to people outside the teams who are appointed by management to facilitate the work teams (Stewart, Manz \& Sims, 1999; Yeatts \& Hyten 1998). They are commonly called facilitators, coordinators, counsellors or coaches. This role is frequently undertaken by middle-level management (Yukl, 2002). Although facilitators are appointed by management similar to supervisors in a traditional work structure, they have different roles and functions in a self-managed work-team structure (Stewart et al., 1999). In a self-managed work team, the role of the facilitator is not so much to direct and control but rather to guide and support the team in reaching performance targets and realising continuous improvement (Wellins et al., 1991). Key decisions, such as hiring and firing, dealing with customers and purchasing equipment, are often still made by external leaders. In addition, activities such as encouraging the team, managing team boundaries and dealing with unexpected problems or events are also commonly performed by external leaders (Morgeson, 2005). Ultimately, the job of a facilitator is to create optimal working conditions so that team members can take on responsibilities to work productively and solve complex problems on their own (Lussier \& Achua, 2007).

One theoretical framework recognised in literature as useful for understanding external team-leader behaviour is founded on conceptual and empirical work on transactional leadership and transformational leadership (Kuo, 2004; \& Pearce \& Sims, 2002; Yammarino, Spangler \& Dubinsky, 1998). The transactionaltransformational leadership paradigm can be extended to both the team and the group context (Bass, 1997). Bass (1997) also found evidence of the presence of transactional-transformational leadership behaviour in various organisations and cultures, such as in India, Spain, Singapore, Japan, China, Germany, Austria and Indonesia.

Transactional leadership behaviour refers to leadership behaviour that entails an exchange between leader and follower (Den Hartog et al., 1997). It is commonly referred to as 'contingentreward based exchanges' (Jung \& Avolio, 1999, p. 208). To play transactional leadership roles, leaders should clarify what is expected from their followers and what they will receive in return for attaining these expectations (Den Hartog et al., 1997). Furthermore, they should provide constructive feedback to keep their followers at task and link extrinsic rewards, such as praise, recognition and monetary reward, to task accomplishment (Jung \& Avolio, 1999; Tracey \& Hinkin, 1998). As a result, employees understand their job roles and the expectations set for them by their leaders and organisations (Avolio, Waldman \& Yammarino, 1991) and the subordinates or followers are confident that they can fulfil expectations and achieve mutually valued outcomes (Bass, 1985). Literature on work teams has also stressed the importance of contingent-reward behaviour to enhance work-team effectiveness. Effective reward systems in a work-team environment are those that provide recognition and reinforcement contingent for excellent team performance (Hackman, 2002; Yeatts \& Hyten, 1998). As such, when leaders of work teams reward team members (in the form of either monetary reward or praise) for the accomplishment of team goals or excellent performance, they exhibit transactional contingent-reward behaviour. Furthermore, Burke et al. (2006) assert that transactional leadership behaviour is likely to be used by team leaders in task-focused behaviour to enhance performance outcomes through task accomplishments by their team members.

An effective work team nevertheless requires external leaders to exhibit not only transactional leadership behaviours but also transformational leadership behaviours. According to Graen and Uhl-Bien (1991), although leader-member exchange may begin with a simple transactional relationship, leaders need to become transformational. 'Transformational leadership' refers to the process whereby an individual engages with others and creates a connection that raises the level of motivation and morality in both the leader and the followers (Northouse, 1997). According to Yammarino et al. (1998), such leadership often uses emotional and/or ideological appeals that change individuals' work values to consider not only themselves but also the larger group or team. Transformational leaders also attempt to raise the needs of their followers and promote change in them and in their groups (Yammarino et al., 1998). These leaders arouse heightened awareness and interest in the groups, increase confidence and gradually move their followers from concerns for existence to concerns for achievement and growth (Avolio et al., 1991; Yammarino et al., 1998). Transformational leaders are also described as those who seek new ways of working, seek opportunities in the face of risk, prefer effective answers to efficient answers and are less likely to support the status quo (Lowe et al., 1996).

Following the transformational leadership conceptualisation from the work of Bass (1985), much literature has suggested four distinct transformational leadership behaviours, 
commonly labelled as the 'Four I's', representing individualised consideration, intellectual stimulation, inspirational motivation and idealised influence (previously referred to as 'charisma') (Avolio et al., 1991; Bass, 1985; Den Hartog et al., 1997). Additionally, Podsakoff et al. (1990), in reviewing the work of various leadership scholars, suggested a much more comprehensive key-behaviours indicator for transformational leaders. They suggest six key behaviours, which greatly overlap with the Four I's but which also have extended features. These six key behaviours are as follows:

- Identifying and articulating a vision. The leader provides vision and a sense of mission, instils pride, gains respect and increases optimism.

- Providing an appropriate model. The leader sets an example for the employees to follow that is consistent with the values that the leader espouses.

- Fostering the acceptance of group goals. The leader promotes cooperation among the employees and encourages them to work together toward a common goal.

- Expecting high performance. The leader demonstrates expectation for excellence, quality and/or high performance on the part of the followers.

- Providing individualised support. The leader shows respect toward the followers and is concerned about their personal feelings and needs.

- Providing intellectual stimulation. The leader challenges the followers to re-examine some of their assumptions about their work and re-think how it can be performed.

Transformational leadership and transactional leadership are viewed as complementary rather than polar constructs, thereby suggesting that effective leaders use a combination of both types of leadership to increase their followers' motivation and performance (Yukl, 2002). Past research has also demonstrated that transformational leadership behaviour has greater influence on team effectiveness than transactional leadership behaviour. Sosik, Avolio and Kahai (1997) reported that both transformational leadership and transactional leadership are positively related to team effectiveness. They found that transformational leadership behaviour, however, has more positive significance and impact on team effectiveness. A recent study conducted by Vecchio et al. (2008) nevertheless suggested that transactional leadership may have greater potential predictive value than previously assumed.

\section{Organisational citizenship behaviour}

Organisational citizenship behaviour is commonly defined as discretionary 'extra role' behaviour not formally rewarded or punished by an organisation that, in the long run, benefits the organisation by improving efficiency and effectiveness (Organ, 1988). Examples of organisational citizenship behaviour include punctuality, helping other employees, volunteering for things that are not required, making innovative suggestions to improve a department and not wasting time (Organ, 1988; Schnake, 1991; Smith et al., 1983). Organisational citizenship behaviour also includes behaviour that a person voluntarily refrains from, such as finding fault with other employees, expressing resentment, complaining about insignificant matters and starting arguments with others (Schnake, 1991). Organisational citizenship behaviour in a work-team context is described as behaviour that extends beyond the prescribed roles and responsibilities of the team members (Randel, 2003). Such behaviour includes efforts that support group cohesion and behaviour that is helpful to task accomplishment in groups (Randel, 2003). High levels of organisational citizenship behaviour are valuable in teams because the complex and dynamic nature of a task and the specialised knowledge and expertise of the team members working in such team environments make it difficult to specify and control individual behaviour (Van der Vegt et al., 2003).
Organ (1988) suggested five dimensions of organisational citizenship behaviour. The first of these is altruism, which refers to voluntary actions that help another person with a work problem, such as instructing a new employee on how to use equipment, helping a co-worker to catch up with a backlog of work or fetching material that a colleague needs and cannot get on his/her own. The second is conscientiousness, which refers to a pattern of behaviour of going well beyond minimally required levels of attendance, punctuality, housekeeping and conserving resources and related matters of internal maintenance. The third is sportsmanship, which refers to behaviour that tolerates inevitable inconvenience and imposition without complaint or grievance. The fourth is courtesy, which refers to all those foresighted gestures that help someone else to prevent a problem, such as keeping others informed of decisions and actions that may affect them (Schnake \& Dumler, 2003). The fifth is civic virtue, which refers to responsible constructive involvement in the political process of an organisation, including not just expressing opinions but also reading mail, attending meetings and keeping abreast of larger issues involving the organisation. Podsakoff et al. (1997), however, asserted that managers often have difficulty in recognising some of these fine distinctions and tend to lump altruism, courtesy, cheer-leading and peacekeeping into a single helping-behaviour dimension. They therefore suggest three dimensions of organisational citizenship behaviour at group level, namely helping behaviour (consisting of altruism, courtesy, peace-keeping and cheer-leading [Organ, 1988]), sportsmanship and civic virtue. This study investigates organisational citizenship behaviour following the dimensions suggested by Podsakoff et al. (1997).

\section{Transformational-transactional leadership behaviour and organisational citizenship behaviour}

Literature and past research have suggested that transformational-transactional leadership behaviour has a positive influence on organisational citizenship behaviour. According to Podsakoff et al. (2000), transactional leadership behaviour may increase employee citizenship behaviour. They suggested that, when managers reward subordinates based on their performance achievement, the subordinates' organisational citizenship behaviour increases. This is because, although managers reward subordinates based on their inrole performance, most often the successful performance of in-role functions requires subordinates to perform extra-role tasks. To gain greater rewards, subordinates therefore exhibit more citizenship behaviour, such as being more helpful and cooperative, in order to perform their in-role functions successfully.

Besides, one of the key characteristics of a self-managed workteam design is the existence of interdependent tasks, goals and rewards to achieve team effectiveness (Campion et al., 1993). Wageman and Baker (1997) suggested that the most interdependent reward system is one in which rewards accrue to a group based on collective performance and are distributed among all members, independent of individual performance. Transactional leadership behaviour in a self-managed work team involves the creation of a contingency between team members' efforts toward the accomplishment of their goals and their receipt of rewards (Yammarino et al., 1998). Team members are often collectively rewarded for the accomplishment of their shared goals and this encourages the team members to work cooperatively to achieve their goals so that they may obtain their rewards. Furthermore, it has been widely recognised that, although organisational citizenship behaviour involves discretionary behaviour not directly rewarded formally, employees may have a broader conception of performance that includes citizenship behaviour (Walumbwa, Wu \& Orwa, 2008). Judge and Piccolo (2004), in their meta-analysis, also suggested that the validity of transactional leadership behaviour is significantly stronger in a business setting compared to 
other settings. A recent study conducted in a school setting nevertheless reported that, even though transactional leadership behaviour had a positive relationship on the teachers' organisational citizenship behaviour, transactional leadership did not explain the significant amount of variance in organisational citizenship behaviour and only transformational leadership behaviour explained the significant amount of variance in the teachers' organisational behaviour (Nguni, Sleegers, \& Denessen, 2006). Similarly, a more recent study conducted on the transformational and transactional leadership behaviour of a Christian pastor on the followers' outcomes, such as extra effort, also reported that transactional leadership had no influence on the followers' extra effort (Rowold, 2008). These findings, however, were contextual in nature. For instance, both studies indicated that very little transactional leadership behaviour was exhibited by the leaders (the head teacher and pastor) due to the nature of their work.

Moreover, from a theoretical perspective, this proposition is supported by the interdependence theory proposed by Deutsch (1949, cited in Van der Vegt \& Van der Vliert, 2002). According to Van der Vegt and Van der Vliert (2002), this theory distinguished two types of outcome or reward interdependence: a cooperative and a competitive context. A cooperative context exists when group members receive or perceive joint goals and receive joint reward for the attainment of their shared goals. A competitive context exists when the goals and rewards of the members are mutually exclusive. Van der Vegt and Van der Vliert (2002) asserted that many studies have tested Deutsch's interdependence theory and have generally shown that a cooperative context is superior to a competitive context in fostering caring and committed relationships, collaborative behaviour, social support, feelings of personal responsibility, intrinsic and achievement motivation, psychological health, feelings of well-being and satisfaction. Additionally, Shaw, Duffy and Stark (2000) suggested that group-based reward structures tend to foster cooperation and diminish competitiveness. Wageman and Baker (1997) also posited that the presence of reward interdependence is critical to eliciting and reinforcing the optimal level of cooperative behaviour that leads to enhanced group performance. When leaders in self-managed work teams therefore provide extrinsic rewards, such as praise, recognition and monetary reward when the team members accomplish their goals, the team members may show higher organisational citizenship behaviour because being cooperative may help them to accomplish their team goals. Based on this premise, the following is hypothesised:

Hypothesis 1 Transactional leadership behaviour has a positive relationship with organisational citizenship behaviour in self-managed work teams.

As for transformational leadership behaviour, studies involving individual work structures have found that this leadership behaviour is positively related to all the five dimensions of organisational citizenship behaviour (Podsakoff et al., 1990; Podsakoff et al., 2000). A study conducted by Lapierre (2007) reported that supervisors' demonstration of benevolence toward their subordinates, which is a form of transformational leadership behaviour, had a positive influence on subordinate willingness to provide their supervisors with extra-role efforts. Yun, Pearce and Sims (2000) reported in their study that, in work-team settings, transformational leadership behaviour was positively associated with team citizenship behaviour. They asserted that the defining characteristic of transformational leaders, which is to inspire and stimulate team members, may result in the team members engaging in positive citizenship behaviour. Following the argument by Smith et al. (1983), transformational leadership, which is characterised by leading, inspiring and stimulating followers, may influence citizenship behaviour in a team context because the leader's behaviour in giving support and showing consideration to the work team, which is a form of citizenship behaviour, is modelled by the team members. Literature has suggested that the essence of transformational leadership is that transformational leaders 'lift ordinary people to extraordinary heights' (Boal \& Bryson, 1988, p. 11) and cause 'followers to do more than they are expected to do' (Yukl, 2002, p. 272).

From a theoretical perspective, the leader supportiveness exhibited by transformational leaders toward their team members initiates a pattern of exchange that is social and non-contractual in character and that creates the norm of reciprocity. According to Blau (1964), 'social exchange' refers to the relationships that entail unspecified future obligations. Social exchange is based on the norm of reciprocity (Gouldner, 1960), which posits that, if one exchange partner does something beneficial for another, an obligation is generated to reciprocate good faith behaviour (Cropanzano \& Mitchell, 2005). Team members may choose citizenship behaviour as a means of reciprocation to their facilitator for exhibiting transformational leadership behaviour. Wayne, Shore and Liden (1997) suggested that the norm of reciprocity creates obligations toward another when that party engaged in a previous behaviour that was beneficial to the recipient. In this context, a leader's supportive behaviour toward team members creates a feeling of obligation in the team members to reciprocate the leader's behaviour. The following is therefore hypothesised:

Hypothesis 2 Transformational leadership behaviour has a positive relationship with organisational citizenship behaviour in self-managed work teams.

\section{Augmenting effects of transactional and transformational leadership}

Although literature has suggested that transformational leadership and transactional leadership are distinct from each other, they are not considered as mutually exclusive processes (Yukl, 2002). As Hater and Bass (1988) pointed out, contrasting transactional leadership and transformational leadership does not imply that the models are unrelated. Both these leadership constructs are viewed as complementary rather than polar constructs (Lowe et al., 1996). Avolio et al. (1991) asserted that transformational leadership behaviour should not be viewed as a replacement for transactional leadership behaviour but that it should rather be viewed as adding to other styles of leadership, such as transactional leadership. Bass (1990) suggested that, while transactional leadership can be effective in stable environments, transformational leadership is important for organisations undergoing rapid and destabilising change.

Literature has further suggested that an effective transformational leadership style requires the existence of a transactional relationship between a leader and their subordinates, and that transformational leadership is likely to be ineffective in the total absence of a transactional relationship between them (Lowe et al., 1996). Literature has, however, suggested that transformational leadership increases follower motivation and performance more than transactional leadership (Den Hartog et al., 1997; Hater \& Bass, 1988). In other words, transformational leadership augments the impact of transactional leadership behaviour on employee outcome but transformational leadership behaviour is unlikely to be effective without transactional leadership behaviour (Den Hartog et al., 1997; Lowe et al., 1996; Podsakoff et al., 1990). Judge and Piccolo (2004), following Bass (1998), defined the augmentation effect as the degree to which the transformational leadership style builds on the transactional base in contributing to the extra effort and performance of followers. They further asserted that transactional leadership results in followers meeting expectations and, in exchange, being rewarded accordingly but that it is transformational leadership that motivates followers to move beyond expectations. This signifies that, without the foundation of transactional leadership, transformational effects may not be possible. These assertions signify that both transformational and transactional leadership behaviour complement each other.

There is also a dissenting view about the augmenting effect of transformational-transactional leadership behaviour on 
leadership outcomes, however, suggesting that transformational leadership adds to transactional leadership but not vice versa (Bycio, Hackett \& Allen, 1995; Judge \& Piccolo, 2004). Judge and Piccolo (2004) argued that, if there were nothing unique to transactional leadership, its scientific and applied value would be called into question. Their findings, however, suggested that both transformational and transactional leaders add scientific and applied value to leadership outcomes. Based on this, the following is therefore hypothesised:

Hypothesis 3 The strength of the relationship between transactional and transformational behaviour in respect of organisational citizenship behaviour is reduced when controlling for either one of the leadership behaviours

\section{RESEARCH DESIGN}

\section{Research approach}

This study followed the quantitative tradition using a crosssectional correlational strategy, as suggested by Gravatter and Forzano (2003), to examine the influence of transformationaltransactional leadership behaviour on organisational citizenship behaviour in self-managed work teams and the augmenting effect of transformational-transactional leadership behaviour. The cross-sectional correlational strategy was chosen because it has been widely used in the field of social science to study relationships among two or more variables (De Vaus, 2004).

Primary data were collected from members of self-managed work teams from a single organisational setting. Many studies on self-managed work teams have been conducted in a single setting (Campion et al., 1993; Cohen et al., 1996; Pearce \& Herbik, 2004; Pearce \& Sims, 2002; Pillai \& Williams, 2004; Van der Vegt, \& Van der Vliert, 2000). Such research has its own strengths in that it enables the control of extraneous influences on the research outcome (Pearce \& Herbik, 2004).

\section{Research method \\ Research participants}

The population of this study comprised 93 self-managed work teams with 520 team members working in a manufacturing company in Malaysia. Each work team comprised three to seven members depending on the nature of the job. The unit of analysis was group level. Hence, at group level, the total population of the 93 self-managed work teams was used as the sample in this study. According to McIntyre and Salas (1995), studies on work teams tend to make inferences on the work team population and not on the members. The use of the group level rather than the individual level of analysis was therefore much more appropriate

Since this study involved a single organisational setting and a group level of analysis was used as the unit of analysis, a non-probability sampling technique was used. According to McIntyre and Salas (1995), it is difficult to use a probability sampling technique for studies examining team behaviour because of the limited number of work teams, especially permanent work teams, in organisations. They therefore asserted that the use of a probability sampling technique as the best sampling technique in such a study is almost impossible. A purposive sampling strategy was used for this study. Only team members who had been assigned directly to a single team and had worked for a year or more were selected as respondents. The reasoning behind the latter criterion was that they were assigned to a permanent work team only after onthe-job training of a year. With that, 472 team members from 93 teams were selected as respondents. Although purposive sampling is used more commonly in qualitative studies, Punch (1998, p. 106) asserted that such a method is also suitable in studies examining relationships among variables because 'it make sense to select the sample in such a way that there is a maximum chance for any relationship to be observed'.

\section{Study setting}

The organisation studied gradually implemented the selfmanaged work-team design from 2001. The self-managed work-team structure was implemented to replace the individual work structure previously practised by the organisation. In the old structure, team members were grouped as crew members working the same shift. In the new self-managed work structure, employees working across various shifts are grouped as work teams and referred to as team members. Each team reports to an external leader referred to as a facilitator and performs interdependent tasks as a team. The team members are empowered with greater responsibilities and are involved in problem-solving and decision-making in their work team. Each team is given an annual target that is monitored on a monthly basis and the team members receive monthly incentives based on the team's achievement of its goal. The monthly target and the amount of the reward are set by management at the start of the year. The facilitator of each team is responsible for coaching and guiding the team members to achieve their performance target. The facilitator is also responsible for most of the functions traditionally performed by an external leader, such as hiring new team members, disciplining team members, dealing with customers, purchasing equipment, helping team members in continuous improvement activities, managing team boundaries and dealing with unexpected problems (Morgeson, 2005; Wellins et al., 1991).

\section{Measures}

Data were collected through self-administered questionnaires. The variables studied were measured with the instrument developed by past researchers, as discussed below. All the items used to assess the variables were measured with a five-point Likert scale ranging from $1=$ 'strongly disagree' to 5 = 'strongly agree'. Since the unit of analysis is group level, all the items in the original instruments using the word ' $\mathrm{I}$ ' or ' $\mathrm{my}$ ' were replaced with 'our' or 'we' to reflect the group-level evaluation.

Transactional leadership behaviour was measured by five items taken by Podsakoff et al. (1990) from Podsakoff, Todor, Grover and Huber (1984) (sample item: 'Our facilitator always gives us positive feedback when we perform well' and 'Our facilitator personally compliments us when we do outstanding work'). The Cronbach's alpha value for this scale was 0.82 . In this study, the transactional leadership behaviour exhibited by the facilitators of the self-managed work teams was assessed based on the team members' evaluation of their facilitators' behaviour.

Transformational leadership behaviour. A total of 24 items was used to assess all six dimensions of transformational leadership behaviour, as suggested by Podsakoff et al. (1990). Twenty-three items were developed following Podsakoff et al. (1990) (sample item: 'Our facilitator shows respect for our personal feelings', 'Our facilitator asks questions that prompt us to think' and 'Our facilitator provides a good model for me to follow'). One additional item, 'Our facilitator states that he/she is confident with our team members' ability to do our best', was constructed for the high-performance expectations dimension by the researchers in this study based on literature review. According to Podsakoff et al. (1990), there are two important aspects to leaders' expectations of high performance: leaders must inform their subordinates of their expectations and leaders must express their confidence in their subordinates' abilities to meet those expectations. Podsakoff et al. (1990) stated that their instrument measured only the first aspect. An additional item was therefore developed to assess the second aspect. The Cronbach's alpha value for this scale was 0.95 . The transformational leadership behaviour exhibited by the facilitators of the self-managed work teams was assessed based on the team members' evaluation of their facilitators' behaviour.

Organisational citizenship behaviour was measured by 13 items assessing three dimensions of organisational citizenship 
behaviour, namely helping behaviour, sportsmanship and civic virtue, following Podsakoff et al. (1997). These items were developed by Podsakoff et al. (1997) and based on the conceptual work of Organ (1988) and the empirical research of Mackenzie, Podsakoff and Fetter (1991), and Podsakoff et al. (1990) (sample item: 'Our team members obey company rules and regulations even when no-one is watching' and 'Our team members help other members who have heavy work loads'). These items were used by Podsakoff et al. (1997) in their study involving work groups. The Cronbach's alpha value for this scale was 0.86 . Since the unit of analysis of this study is group level, the referentshift approach of Chan (1998) was adopted to assess team-level organisational citizenship behaviour through the individual team member's assessments of the overall team members' organisational citizenship behaviour. All items thus used the words 'Our team members . . .. Furthermore, the referent-shift approach could help to reduce self-report bias arising from team members' tendency to respond in socially desirable ways when assessing their own organisational citizenship behaviour.

\section{Research procedure}

Written approval was obtained from the organisation for the researcher, with the assistance of a Human Resource Department officer, to collect data for this research through group-administered questionnaires. The Human Resource Officer prepared the schedule for 15 face-to-face group meetings involving approximately 25 respondents. The respondents were informed that participation was voluntary. At each meeting, the purpose and procedures were explained. The respondents were then handed a questionnaire and asked to complete it while in the room (Trochim, 2006). This procedure enabled the researcher to stay in control of the data collection. For example, the researcher was able to explain questions that respondents found unclear and provide detailed instructions where necessary (Rea \& Parker, 2005). This method of data collection also yields a high response rate (Trochim, 2006). A total of 420 responses was obtained, which accounted for $89 \%$ of the response rate.

\section{Analysis of data at individual and at group level}

Several statistical techniques were used in this study for the purpose of the analysis of the data. A descriptive statistical analysis with frequency distribution and mean and standard deviation was used to describe the demographic profile at the individual and at the group level of analysis and to describe the variables of the study.

According to Kirkman and Rosen (1999), researchers can measure team-level phenomena using individual members' data and then aggregating these to team level. Many researchers of work teams and groups have aggregated data obtained at individual level at group level for the purpose of analysis (Campion et al., 1993; Darch-Zahavy \& Somech, 2002; Doolen, 2001; George \& Bettenhausen, 1990). Since the unit of analysis used in this study was group level, the data obtained from the respondents at individual level were aggregated to group level following the recommendations of Kirkman and Rosen (1999). The data aggregation was performed using the SPSS version 15 by averaging the individual responses for each independent and dependent variable across all the team members and by using the mean team scores for the independent and dependent variables as measures for analysis, following James, Demaree and Wolf (1984).

In order to determine whether data can be aggregated from individual to group level, two tests were performed following Doolen (2001) and George and Bettenhausen (1990). The two tests were 1) the inter-rater agreement test and 2) the differences between groups test. The inter-rater agreement $\left(r_{w r(i)}\right)$ was tested with the formula suggested by James et al. (1984). If the inter-rater agreement score is $r_{w g(i)}=0.7$ or higher, the level of agreement is high and individual-level data can be aggregated to group level (George \& Bettenhausen, 1990; James et al., 1984).
TABLE 1

Inter-rater agreement and differences between groups $(n=93)$

\begin{tabular}{lcc}
\hline VARIABLE & $\begin{array}{c}\text { INTER-RATER } \\
\text { AGREEMENT } r_{\text {wg(i) }} \\
\text { (Median value) }\end{array}$ & $\begin{array}{c}\text { DIFFERENCES } \\
\text { BETWEEN } \\
\text { GROUPS } \\
\text { (F ratio) }\end{array}$ \\
\hline Transactional leadership behaviour & $0.98^{*}$ & $2.12^{* *}$ \\
Transformational leadership behaviour & $0.99^{*}$ & $1.55^{* *}$ \\
Organisational citizenship behaviour & $0.97^{*}$ & $1.43^{* *}$ \\
\hline
\end{tabular}

${ }^{*} r_{w g(i)}>0.7 \quad * * F$ ratio $>1$

The second test was performed using the analysis of variance (ANOVA). If the $F$ value obtained is greater than $1.00(F>1.00)$, a difference between groups is considered to exist (George \& Bettenhausen, 1990) and aggregation to the group level of analysis is appropriate. The results of the aggregation analysis, as shown in Table 1, indicated that both conditions were met. The data in this study could therefore be aggregated to group level.

Finally, the aggregated data were statistically analysed using Pearson correlation, partial correlation and multiple regression. The statistical significance at $p=.05$ was used in this study as the cut-off point for significance.

\section{RESULTS \\ Demographic profile of respondents at individual and group level of analysis}

Table 2 presents the demographic profile of the respondents at the individual and at the group level of analysis. The average age of the respondents was 25 and ranged from 18 to 42 . The majority of the respondents $(98.8 \%)$ were from the Malay ethnic group. The majority $(69.8 \%)$ were also male and most $(66.7 \%)$ were single. Most of the respondents (82.1\%) had attained the highest level of secondary-school education. The average tenure of the respondents with the organisation was five years. More than half $(62.9 \%)$ had served the company for less than six years. Most (64\%) were production operators. They comprised the largest number of workers on the production floor. The majority $(82.9 \%)$ of the respondents worked three-shift cycles. Most of the teams $(79.6 \%)$ were from the Production Department.

\section{Relationship between transactional and transformational leadership behaviour in respect of organisational citizenship behaviour}

Table 3 reports the mean standard deviation, correlation and partial correlation concerning the variables of study. Since multiple-item measures were used to assess the variables in this study, a composite score was computed for all three variables of study. Since the total score for each variable varied due to the different number of items used, the weighted mean score was used for ease of interpretation. With that, a standard score between 1 and 5 was used for all the variables. The mean value obtained indicated that the self-managed work-team leaders in the organisation possessed higher transformational leadership behaviour $(M=4.09, S D=0.25)$ compared to transactional leadership behaviour $(M=3.45, S D=0.36)$.

The results also revealed that both transactional leadership behaviour $(r(93)=0.48, p<0.01)$ and transformational leadership behaviour $(r(93)=.63, p<.01)$ were significantly and positively related to organisational citizenship behaviour $(M=3.58, S D$ $=0.27$ ). The results showed that transformational leadership behaviourhad a stronger positiverelationship with organisational citizenship behaviour compared to transformational leadership behaviour. Both Hypothesis 1 and Hypothesis 2 were therefore supported by this study. 
TABLE 2

Demographic profile of respondents at individual $(n=420)$ and group level of analysis $(n=83)$

\begin{tabular}{|c|c|c|c|c|}
\hline \multicolumn{3}{|c|}{ VARIABLE } & FREQUENCY & PERCENTAGE (\%) \\
\hline \multicolumn{5}{|c|}{ INDIVIDUAL LEVEL OF ANALYSIS ( $n=420)$} \\
\hline \multirow[t]{3}{*}{1.} & Gender & & & \\
\hline & a) & Male & 293 & 69.8 \\
\hline & b) & Female & 127 & 30.2 \\
\hline \multirow[t]{3}{*}{2.} & Ethnic group & & & \\
\hline & a) & Malay & 415 & 98.8 \\
\hline & b) & Indian & 5 & 1.2 \\
\hline \multirow[t]{4}{*}{3.} & Marital status & & & \\
\hline & a) & Single & 280 & 66.7 \\
\hline & b) & Married & 138 & 32.9 \\
\hline & c) & Widowed/Divorced & 2 & 0.5 \\
\hline \multirow[t]{6}{*}{4.} & Age & & & \\
\hline & a) & $18-22$ years & 136 & 38.0 \\
\hline & b) & $23-27$ years & 155 & 43.3 \\
\hline & c) & $28-32$ years & 40 & 11.2 \\
\hline & d) & 33-37 years & 21 & 5.9 \\
\hline & e) & $38-42$ years & 6 & 1.7 \\
\hline \multirow[t]{6}{*}{5.} & Education leve & & & \\
\hline & a) & Lower secondary (SRP/PMR) & 8 & 2.0 \\
\hline & b) & Upper secondary (SPM) & 345 & 84.8 \\
\hline & c) & A-level (STPM) & 29 & 7.1 \\
\hline & d) & Certificate & 20 & 4.9 \\
\hline & e) & Diploma & 5 & 1.2 \\
\hline \multirow[t]{5}{*}{6.} & Years of servic & & & \\
\hline & a) & $1-3$ years & 187 & 44.5 \\
\hline & b) & $4-6$ years & 77 & 18.3 \\
\hline & c) & $7-9$ years & 56 & 13.3 \\
\hline & d) & $10-13$ years & 51 & 12.1 \\
\hline \multirow[t]{5}{*}{7.} & Shift schedule & & & \\
\hline & a) & Shift 1 (08:00-16:00) & 212 & 50.5 \\
\hline & b) & Shift 2(16:00-24:00) & 109 & 26.0 \\
\hline & c) & Shift 3(24:00-08:00 & 27 & 6.4 \\
\hline & d) & Normal (08:00-16:00) & 72 & 17.1 \\
\hline \multirow[t]{5}{*}{8.} & Position & & & \\
\hline & a) & Production Operator & 269 & 64.0 \\
\hline & b) & Quality Inspector & 52 & 12.4 \\
\hline & c) & Technician & 25 & 6.0 \\
\hline & d) & Production Support & 74 & 17.6 \\
\hline \multicolumn{5}{|c|}{ GROUP LEVEL OF ANALYSIS ( $n=93$ ) } \\
\hline \multirow[t]{4}{*}{9.} & Number of tear & per department & & \\
\hline & a) & Production Department & 74 & 79.6 \\
\hline & b) & Quality Department & 13 & 14.0 \\
\hline & c) & Maintenance Department & 6 & 6.5 \\
\hline
\end{tabular}

A regression analysis, as shown in Table 4, was performed to determine the extent to which both these leadership behaviours influenced self-managed work-team organisational citizenship behaviour. The results of the regression revealed that both these leadership behaviours explained a sizeable proportion of variance $\left(R^{2}=0.40, F(2,90)=30.49\right.$ and $\left.p<0.05\right)$ in selfmanaged work-team organisational citizenship behaviour. This indicated that both these leadership behaviours contributed approximately $40 \%$ to organisational citizenship behaviour in the self-managed work team studied. Transactional leadership behaviour nevertheless did not predict self-managed work-team organisational citizenship behaviour $(\beta=0.05, p>0.05)$. Only transformational leadership behaviour predicted self-managed work-team organisational citizenship behaviour $(\beta=0.60, p<$ 0.05).

\section{Augmenting effect of transformational- transactional leadership behaviour on organisational citizenship behaviour}

A partial correlation analysis, as shown in Table 3, was used to explore the relationship between transactional leadership behaviour and organisational citizenship behaviour while controlling for transformational leadership behaviour and the relationship between transformational leadership behaviour and organisational citizenship behaviour while controlling for transactional leadership behaviour. Results revealed that there was no relationship between transactional leadership behaviour and organisational citizenship behaviour while controlling for transformational leadership behaviour $(r(93)=0.05, p>0.05)$. This suggested that controlling for transformational leadership behaviourhad a significanteffect on thestrength of the relationship 
TABLE 3

Means, standard deviations, zero order and partial correlations for study variables

\begin{tabular}{lllllll}
\hline & & & \multicolumn{3}{c}{$r$} & partial $r$ \\
\cline { 5 - 6 } VARIABLES & MEAN & SD & OCB & TCLB & TSLB & OCB \\
\hline OCB & 3.58 & 0.27 & & & \\
TCLB & 3.45 & 0.36 & $0.48\left(^{* *}\right)$ & & 0.05 \\
TSLB & 4.09 & 0.25 & $\left.0.63^{* *}\right)$ & $\left.0.72^{(* *}\right)$ & $0.48\left(^{* *}\right)$ \\
\hline
\end{tabular}

${ }^{*} p<0.05,{ }^{* *} p<0.01$

$\mathrm{OCB}=$ organisational citizenship behaviour, $\mathrm{TCLB}=$ transactional leadership behaviour, TSLB = transformational leadership behaviour

Note the partial correlation between transactional leadership behaviour and organisational citizenship behaviour after controlling for transformational leadership beviour, the partial correlation between transformation leadership behaviour behaviour, the parial corelion between transformational leadership behaviour behaviour

TABLE 4

Summary of multiple-regression analysis of influence of transactional and transformational leadership behaviour on organisational citizenship behaviour

\begin{tabular}{llllll}
\hline VARIABLE & $\boldsymbol{\beta}$ & $\boldsymbol{t}$ & $\boldsymbol{p}$ & $\mathbf{F}$ & $\mathbf{R}^{2}$ \\
\hline Transactional leadership behaviour & 0.05 & 0.46 & 0.65 & $30.49^{* *}$ & 0.4 \\
Transformational leadership behaviour & 0.6 & $5.12^{* *}$ & 0.01 & & \\
\hline
\end{tabular}

Standardised regression coefficients are reported. ${ }^{* \star} p<0.01$

between transactional leadership behaviour and organisational citizenship behaviour. There was a moderate positive significant relationship between transformational leadership behaviour and organisational citizenship behaviour while controlling for transactional leadership behaviour $(r(93)=0.46, p<0.05)$. The strength of the relationship, however, had reduced compared to the original bivariate correlation. This suggested that controlling for transactional leadership behaviour had little effect on the strength of the relationship between transformational leadership behaviour and organisational citizenship behaviour. Hypothesis 3 was therefore supported by this study.

\section{DISCUSSION}

This study aimed to examine the influence of transactionaltransformational leadership behaviour on organisational citizenship behaviour in self-managed work teams and the augmenting effect of transformational-transactional leadership behaviour on its relationship with organisational citizenship behaviour. The focus of the study was on external leaders referred to as 'facilitators' of the self-managed work team in the organisation studied. External leaders are people outside the teams who are appointed by management to facilitate the work teams. They play an important role in team effectiveness (Morgeson, 2005; Stewart et al., 1999; Yeatts \& Hyten, 1998).

The findings of this study revealed that the work teams perceived their facilitators to possess both types of leadership behaviours, although transformational leadership behaviour seemed to be stronger than transactional leadership behaviour. The findings also revealed that both leadership behaviours correlated positively with organisational citizenship behaviour in the self-managed work teams. Further analysis, however, revealed that only transformational leadership predicted organisational citizenship behaviour. This was consistent with the assertion by Bass (1990) that transactional leadership is effective in stable organisations, while transformational leadership is much more important in organisations undergoing rapid and destabilising change, as was found to be the case in the organisation that was studied. During the preliminary investigation, this study found that the self-managed work-team structure had been implemented to replace the individual work structure that had previously been practised by the organisation. The facilitators could therefore focus more on engaging in transformational leadership behaviour to take the work teams to greater heights and change their mind-sets from focusing on individual achievement to focusing on collective goals and achievements. This explained the team members perceiving their facilitators to display stronger transformational leadership behaviour.

The results of this study showed that transformational leadership had a positive influence and predicted the organisational citizenship behaviour of the teams. These results were consistent with the assertion that transformational leadership is responsible for performance beyond expectation and that its motivational potential surpasses that of leadership models characterised by leader-follower exchanges or of transactions as exhibited in transactional leadership behaviour (Hater \& Bass, 1988). The results were also consistent with literature and past research, which has suggested that transformational leadership behaviour has a positive influence on organisational citizenship behaviour (Podsakoff et al., 1997; Podsakoff et al., 2000; Nguni et al., 2006; Yukl 2002). The theoretical explanation of the relationship between transformational leadership behaviour and organisational citizenship behaviour using the social-exchange theory was also supported. The social-exchange theory suggests that leader supportiveness exhibited by transformational leaders toward their team members initiates a pattern of exchange that is social and non-contractual in character and that creates the norm of reciprocity in which team members choose citizenship behaviour as a means of reciprocation (Cropanzano \& Mitchell, 2005; Wayne et al., 1997) for the positive leadership behaviour shown by their facilitators.

The findings of this study showed that, although there was a relationship between the transactional leadership behaviour and the organisational citizenship behaviour of the self-managed work teams, this leadership behaviour had no influence on organisational citizenship behaviour. This was consistent with the results of recent studies by Rowold (2008) and Nguni et al. (2006). The facilitators in this study did not have direct control over the amount of monthly incentives that their team members received, as this had been set by management. Facilitators generally do not have direct control over the amount of rewards to be granted because team rewards are based on the achievement of targets, measured quantitatively. Not much transactional exchange between facilitators and their team members that elicits organisational citizenship behaviour therefore occurs. Facilitators may, however, provide their team members with encouragement, guidance, motivation and inspiration, which are defining characteristics of transformational leadership behaviour and which may result in team members engaging in organisational citizenship behaviour. This was evident from the findings of this study, which showed that the team members perceived their facilitators to engage more in transformational leadership than in transactional leadership. Judge and Piccolo (2004) reported in their meta-analysis that transformational leadership behaviour is a stronger predictor for criteria that reflect follower satisfaction and motivation and that transactional leadership behaviour tends to have a stronger influence on in-role performance. Burke et al. (2006) also suggested that transactional leadership behaviour is likely to be used by team leaders to complete task-focused behaviour for performance outcomes to be enhanced. Transactional leadership behaviour therefore may have a stronger influence on team performance and transformational leadership behaviour may have a stronger influence on organisational citizenship behaviour in selfmanaged work teams.

The results of this study also supported the augmenting hypothesis of transformational-transactional leadership obtaining performance beyond basic expectation (Lowe et al. 1996). The results revealed that the sole use of transactional leadership behaviour in the total absence of transformational leadership behaviour did not enhance organisational citizenship behaviour in the work teams and that effective transformational leadership required the existence of a transactional relationship 
between the leaders and the followers. Although the results revealed that transformational leadership behaviour had a stronger influence on organisational citizenship, such behaviour should not be viewed as a replacement for transactional leadership behaviour (Avolio et al., 1991) but should rather add to other styles of leadership, such as the transactional leadership style. While each of these two leadership behaviours individually correlates with organisational citizenship behaviour, both behaviours operate most effectively in combination. Both are viewed as complementary constructs rather than polar constructs (Lowe et al., 1996). As Lowe et al. (1996) suggest, transformational leadership seeks new ways of working, it seeks opportunities in the face of risk and it tends to utilise symbolism and imagery to solicit increased effort. Transactional strategies may also be used when appropriate, however, transformational leadership is likely to be ineffective in the total absence of a transactional relationship between leaders and their subordinates. This study found that both transactional and transformational leadership behaviours were important in enhancing organisational citizenship behaviour in self-managed work teams. Even though transformational leadership behaviour has a greater influence on organisational citizenship behaviour, both these leadership behaviours operate most effectively in combination.

\section{Implications, limitations and suggestions for further research}

The findings of this study support the theoretical propositions on the contribution of transformational and transactional leadership behaviour in influencing citizenship behaviour among team members. The findings also support the propositions that transformational leadership behaviour augments transactional leadership behaviour in influencing work teams to engage in organisational citizenship behaviour. The study furthermore contributes to theory development and research on organisational citizenship behaviour by examining the influence of leadership behaviour on organisational citizenship behaviour at group level. Schnake and Dumler (2003) asserted that organisational citizenship behaviour theory and research that omit specific consideration of levels issues are considered incomplete. Practically, this study suggests the importance of external leaders in engaging in both these leadership behaviours to motivate work teams to engage in organisational citizenship behaviour, such as helping other team members, performing tasks beyond their roles and responsibilities and being supportive of organisational and work-team efforts. External leaders should therefore rely not only on reward exchange behaviour as a way to encourage organisational citizenship behaviour among team members.

Nevertheless, from the partial-correlation and multipleregression results, one may argue that a spurious relationship exists between transactional leadership behaviour and organisational citizenship behaviour, which is due to the fact that both variables are influenced by transformational leadership behaviour. This supports the dissenting view about the augmenting effect of transformational-transactional leadership behaviour that suggests transformational leadership adds to transactional leadership but not vice versa (Bycio et al., 1995; Judge \& Piccolo, 2004). It can be argued that whatever validity there is to transactional leadership, it is due to its association with transformational leadership, which is also evident in this study. As Judge and Piccolo (2004) noted, if the positive effects of transactional leadership are simple byproducts of transformational leadership, there is nothing unique to transactional leadership and, if this is so, its scientific and applied value would be called into serious question.

One main limitation of this study is that it was conducted in a single study setting. The findings of the study therefore cannot be generalised and more studies are needed to research this phenomenon in various organisations. Another limitation of this study is that the influence of transactional and transformational leadership behaviour on work teams' in-role performance was not considered. A study including this would therefore provide greater insight into understanding the extent to which both these leadership behaviours influence not only 'extra-role' performance but also 'in-role' performance. Previous studies have also reported that transactional leadership behaviour has a stronger influence on performance-related outcome (Judge \& Piccolo, 2004). It may thus be possible that both these leadership behaviours have varying degrees of influence depending on the types of outcomes. This study therefore suggests further studies to examine these relationships. Furthermore, from methodological perspectives, the use of partial correlation and regression may not be able to fully explain the transactionaltransformational leadership behaviour model and its influence on organisational citizenship behaviour. The basic statistical methods are not sufficient to test the hypothesised model in a simultaneous analysis of the entire system of variables (Byrne, 2001; Schumacher \& Lomax, 2004). For that, further research with a structural modelling technique is recommended to better understand the phenomenon of the study. Finally, considering the high intercorrelations between transactional and transformational leadership behaviour, as indicated in past studies (Judge \& Piccolo, 2004; Nguni et al., 2006; Rowold, 2008), further study is needed to re-examine the transformationaltransactional leadership construct.

\section{REFERENCES}

Avolio, B.J., Waldman, D.A., \& Yammarino, F.J. (1991). Leading in the 1990s: The four I's of transformational leadership. Journal of European Industrial Training, 15(4), 9-16.

Bass, B. (1985). Leadership and performance beyond expectations. New York: Free Press.

Bass, B. (1990). From transactional to transformational leadership: Learning to share the vision. Organizational Dynamics, 18(3), 19-32.

Bass, B.M. (1997). Does the transactional-transformational leadership paradigm transcend organizational and national boundaries? American Psychologist, 52(2), 130-139.

Bass, B.M. (1998). Transformational leadership: Industry, military, and educational impact. Mahwah: Lawrence Erlbaum.

Blau, P. (1964). Exchange and power in social life. New York: John Wiley.

Boal, K.B., \& Bryson, J.M. (1988). Charismatic leadership: A phenomenological and structural approach. In J.G. Hunt, B.R. Baliga, H.P. Dachler, \& C.A. Schrieshiem (Eds.), Emerging leadership vistas, (pp. 5-28). Lexington: Lexington Books.

Borman, W.C. (2004). The concept of organizational citizenship. Current Directions in Psychological Science, 13(6), 238-241.

Burke, C.S., Stagl, K.C., Klien, C., Goodwin, G.F., Salas, E., \& Halpin, S.M. (2006). What types of leadership behaviours are functional in teams: A meta-analysis. The Leadership Quarterly, 17, 288-307.

Bycio, P., Hackett, R.D., \& Allen, J.S. (1995). Further assessments of Bass's (1985) conceptualization of transactional and transformational leadership. Journal of Applied Psychology, $80,468-478$

Byrne, B. (2001). Structural equation modelling with AMOS. Mahwah: Lawrence Erlbaum Associates.

Campion, M.A., Medsker, G.J., \& Higgs, A.C. (1993). Relations between work group characteristics and effectiveness: Implications for designing effective work groups. Personnel Psychology, 46, 823-850.

Cappelli, P., \& Rogovski, N. (1998). Employee involvement and organizational citizenship behaviour: Implications for labour law reform and lean production. Industrial Labor Relations Review, 51(4), 633-655.

Chan, D. (1998). Functional relations among constructs in the same content domain at different levels of analysis: A typology of composition models. Journal of Applied Psychology, 83(2), 234-246. 
Cohen, S.G., Ledford, G.E., Jr., \& Spreitzer, G.M. (1996). A predictive model of self managing work team effectiveness. Human Relations, 49(5), 643-677.

Cropanzano, R., \& Mitchell, M.S. (2005). Social exchange theory: An interdisciplinary review. Journal of Management, 31, 874900.

Darch-Zahavy, A., \& Somech, A. (2002). Team heterogeneity and its relationship with team support and team effectiveness. Journal of Educational Administration, 40(1), 44-66.

Den Hartog, D.D., Van Muijen, J.J., \& Koopman, P. (1997) Transactional versus transformational leadership: An analysis of the MLQ. Journal of Occupational and Organizational Psychology, 70, 19-34.

De Vaus, D. (2002). Analyzing social science data. London: Sage Publications.

Doolen, T.L. (2001). The impact of organizational context on work team effectiveness: A study of production and engineering teams. Dissertation Abstracts International. (UMI No. 3015203).

Farh, J.L., Zhong, C.B., \& Organ, D.W. (2004). Organizational citizenship behaviour in the People's Republic of China. Organization Science, 15(2), 241-253.

George, J.M., \& Bettenhausen, K. (1990). Understanding prosocial behaviour, sales performance, and turnover: A group level analysis in a service context. Journal of Applied Psychology, 75(6), 698-709.

Gouldner, A.W. (1960). The psychology of behavioural exchange. Reading, MA: Addison-Wesley.

Graen, G.B., \& Uhl-Bien, M. (1991). The transformation of professionals into self-managing and partially selfdesigning contributors towards a theory of leadershipmaking. Journal of Management Systems, 3, 33-48.

Gravatter, F.J., \& Forzano, L.B. (2003). Research methods for the behavioural science. Belmont: Wadsworth/Thomson Learning.

Hackman, J.R. (2002). Leading teams: Setting the stage for great performances. Boston: Harvard Business School Press.

Hater, J., \& Bass, B. (1988). Superiors' evaluation and subordinates' perceptions of transformational and transactional leadership. Journal of Applied Psychology, 73(3), 695-702.

James, L.R., Demaree, R.C., \& Wolf, G. (1984). Estimating withingroup interrater reliability with and without response bias. Journal of Applied Psychology, 69(1), 85-98.

Judge, T.A., \& Piccolo, R.F. (2004). Transformational and transactional leadership: A meta-analytic test of their relative validity. Journal of Applied Psychology, 89(5), 755768.

Jung, D.I., \& Avolio, B.J. (1999). Effects of leadership style and followers' cultural orientation and performance in group and individual task conditions. Academy of Management Journal, 42(2), 208-218.

Katzenbach, J.R., \& Smith, D.K. (1993). The wisdom of teams. New York: Harvard Business School Press.

Kirkman, B.L., \& Rosen, B. (1999). Beyond self-management: Antecedents and consequences of team empowerment. Academy of Management Journal, 42(1), 58-74.

Kuo, C.C. (2004). Research on impacts of team leadership and team effectiveness. The Journal of American Academy of Business, September, 266-278.

Lapierre, L.L. (2007). Supervisor trustworthiness and subordinates' willingness to provide extra-role efforts. Journal of Applied Social Psychology, 37(2), 272-297.

LePine, J.A., Erez, A., \& Johnson, D.E. (2002). The nature and dimensionality of organizational citizenship behaviour: A critical review and meta-analysis. Journal of Applied Psychology, 87(1), 52-65.

Lim, B.C., \& Polyhart, R.E. (2004). Transformational leadership: Relations to the five-factor model and team performance in typical and maximum context. Journal of Applied Psychology, 89(4), 610-621.

Lowe, K.B., Kroeck, K.K., \& Sivasubramaniam, N. (1996). Effectiveness correlates of transformational and transactional leadership: A meta-analytic review of the MLQ literature. Leadership Quarterly, 7(3), 385-427.

Lussier, R.N., \& Achua, C.F. (2007). Leadership: Theory, application, skill development. Mason: Thomson Higher Education.

MacKenzie, S.B., Podsakoff, P.M., \& Fetter, R. (1991). Organizational citizenship behaviour and objective productivity as determinants of managerial evaluations of salespersons' performance. Organizational Behaviour and Human Decision Processes, 50, 123-150.

Manz, C.C., \& Sims, H.P. (1993). Business without bosses: How self managing teams are building high performing companies. New York: John Wiley \& Sons.

McIntyre, R.M., \& Salas, M. (1995). Measuring and managing for team performance: Emerging principles form complex environments. In R.A. Guzzo, E. Salas, \& Associates (Eds.), Team effectiveness and decision making in organizations, (pp. 9-45). San Francisco: Jossey-Bass.

Morgeson, F.P. (2005). The external leadership of self-managing teams: Intervening the context of novel and disruptive events. Journal of Applied Psychology, 90(3), 497-508.

Nguni, S., Sleegers, P., \& Denessen, E. (2006). Transformational and transactional leadership effects on teachers' job satisfaction, organizational commitment and organizational citizenship behaviour in primary schools: The Tanzanian case. School Effectiveness and School Improvement, 17(2), 145177.

Northouse, P.G. (1997). Leadership theory and practice. Thousand Oaks: Sage Publications.

O'Connell, M., Doverspike, D., \& Cober, A.B. (2002). Leadership and semiautonomous work team performance. Group and Organization Management, 27(1), 50-65.

Organ, D.W. (1988). Organizational citizenship behaviour: The good soldier syndrome. Lexington: Lexington Books.

Pearce, C.L., \& Herbik, P. (2004). Citizenship behaviour at the team level of analysis: The effects of team leadership, team commitment, perceived team support, and team size. The Journal of Social Psychology, 144(3), 293-310.

Pearce, C.L., \& Sims, H.P. (2002). Vertical versus shared leadership as predictors of the effectiveness of change management teams: An examination of aversive, directive, transactional and empowering leader behaviours. Group Dynamics: Theory, Research and Practice, 6(2), 172-197.

Pillai, R., \& Williams, E.A. (2004). Transformational leadership, self-efficacy, group cohesiveness, commitment and performance. Journal of Organizational Change Management, 17(2), 144-159.

Podsakoff, P.M., Ahearne, M., \& MacKenzie, S.B. (1997). Organization citizenship behaviour and the quantity and quality of work group performance. Journal of Applied Psychology, 82(2), 262-270.

Podsakoff, P.M., Mackenzie, S.B., Moorman, R.H., \& Fetter, R. (1990). Transformational leader behaviours, and their effects on followers' trust in leader, satisfaction, and organizational citizenship behaviours. Leadership Quarterly, 1(2), 107-142.

Podsakoff, P.M., MacKenzie, S.B., Paine, J.B., \& Bachrach, D.G. (2000). Organizational citizenship behaviours: A critical review of the theoretical and empirical literature and suggestions for future research. Journal of Management, 26(3), 513-563.

Podsakoff, P.M., Todor, W.D., \& Skov, R. (1982). Effect of leader contingent and non-contingent reward and punishment behaviors on subordinate performance and satisfaction. Academy of Management Journal, 25, 810-821.

Podsakoff, P. M., Todor, W. D., Grover, R. A. \& Huber, V.L. (1984). Situational moderators of leader reward and punishment behaviors: Fact or fiction? Organizational Behavior and Human Performance, 34(1), 1-63.

Punch, K.F. (1998). Introduction to social research: Quantitative and qualitative approaches. London: Sage Publications.

Randel, A.E. (2003). The salience of culture in multinational teams and its relations to team citizenship behaviour. International Journal of Cross Cultural Management, 3(1), 2744. 
Rea, L.M., \& Parker, R.A. (2005). Designing \& conducting survey research: A comprehensive guide. San Francisco: Jossey Bass.

Rowold, J. (2008). Effects of transactional and transformational leadership of pastors. Pastoral Psychology, 56, 403-411.

Schnake, M. (1991). Organizational citizenship: A review, proposed model and research agenda. Human Relations, 44(7), 735-759.

Schnake, M., \& Dumler, M.P. (2003). Levels of measurement and analysis issues in organizational citizenship behaviour research. Journal of Occupational and Organizational Psychology, 76, 283-301.

Schumacher, R.E., \& Lomax, R.G. (2004). A beginner's guide to structural equation modeling. Mahwah: Lawrence Erlbaum Associates.

Shaw, J.D., Duffy, M.K., \& Stark, E.M. (2000). Interdependence and preference for group work: Main and congruence effects on the satisfaction and performance of group members. Journal of Management, 26(2), 259-279.

Smith, C.A., Organ, D.W., \& Near, J.P. (1983). Organizational citizenship behaviour: Its nature and antecedents. Journal of Applied Psychology, 68(4), 653-663.

Sosik, J.J., Avolio, B.J., \& Kahai, S.S. (1997). Effects of leadership style and anonymity on group potency and effectiveness in a group decision support system environment. Journal of Applied Psychology, 82(21), 89-103.

Stewart, G.L., Manz, C.C., \& Sims, H.P. (1999). Team work and group dynamics. New York: John Wiley and Sons Inc.

Tracey, J.B., \& Hinkin, T.R. (1998). Transformational leadership or effective managerial practices? Group and Organization Management, 23(3), 220-236.

Trochim, W.M. (2006). The Research Methods Knowledge Base. (2nd edn.). Retrieved January, 2008, from http://www. socialresearchmethods.net $/ \mathrm{kb} /$

Van der Vegt, G.S., \& Van der Vliert, E. (2002). Intra-group interdependence and effectiveness: Review and proposed directions for theory and practice. Journal of Managerial Psychology, 17(1), 50-67.
Van der Vegt, G.S., Van de Vliert, E., \& Oosterhof, A. (2003). Informational dissimilarity and organizational citizenship behaviour: The role of intra-team, interdependence and team identification. Academy of Management Journal, 46(6), $715-725$.

Vecchio, R.P., Justin, J.E., \& Pearce, C.L. (2008). The utility of transactional and transformational leadership for predicting performance and satisfaction within a path-goal theory framework. Journal of Occupational and Organizational Psychology, 81, 71-82.

Wageman, R., \& Baker, G. (1997). Incentives and cooperation: The joint effects of task and reward interdependence on group performance. Journal of Organizational Behaviour, 18, 139-158.

Walumbwa, F.O., Wu, C., \& Orwa, B. (2008). Contingent reward transactional leadership, work attitudes, and organizational citizenship behavior: The role of procedural justice climate perceptions and strength. The Leadership Quarterly, 19, 251265.

Wayne, S.J., Shore L.M., \& Liden, R.C. (1997). Perceived organizational support and leader-member exchange: A social exchange perspective. Academy of Management Journal, 40(1), 82-111.

Wellins, R.S., Byham, W.C., \& Wilson, J.M. (1991). Empowered teams: Creating self directed groups that improve quality, productivity, and participation. San Francisco: Jossey Bass.

Yammarino, F.J., Spangler, W.D., \& Dubinsky, A.J. (1998). Transformational and contingent reward leadership: Individual, dyad and group level of analysis. Leadership Quality, 9(1), 27-55.

Yeatts, D.E., \& Hyten, C. (1998). High performing self-managed work teams: A comparison of theory to practice. Thousand Oaks: Sage Publications.

Yukl, G. (2002). Leadership in organizations. (5th edn.). New Jersey: Prentice Hall.

Yun, S., Pearce, C.L., \& Sims, H.P. (2000). Leadership, team OCB, collective efficacy and team performance. Paper presented at the Academy of Management, Toronto. 